\title{
Brexit: an exit disaster or entry into a Kafkaesque process? Reflections from a Danish education and research context
}

John Benedicto Krejsler (jok@edu.au.dk)

Aarhus University, Denmark

What will Brexit mean for the UK and the EU? This commentary argues that Brexit will occupy the EU for years, and work as a brake on the EU as Brexit appears to represent a radical echo of popular dissatisfaction with the EU in most member states. EU and the UK are so interwoven that a solution will be brokered that reflects common trade, cultural and security interests. Brexit, however, also reflects the unfair and infantilized image of the EU as 'the bureaucratic giant thwarting national sovereignty' that is repeatedly echoed in national debates. This actualizes two main problems to be dealt with: (1)EU's onesided focus on market interests, and (2) its democratic deficit. BUT: EU is necessary to prevent European nation states from reverting to inward-looking national(ist) perspectives in a globalized world. EU forces us to widen horizons. EU is also a project of cultural exchange, diversity and Bildung.

\section{What actually happened?}

On 24 June 2016 52\% 'brexiteers' against 48\% 'remainers' decided to vote the UK out of the EU with a turnout of $71.8 \%$ of the electorate. It was, by any definition, a motley vote: cosmopolitan London, independence-hungry Scotland and divided Northern Ireland voted to remain, and the rest of the country voted to leave the EU; it was young against old; educated against low-skilled. It was a vote that reflected the issue of who is riding the globalisation gravy train, and who feels left behind. Although Brexit represents a particular British showdown with Europe ${ }^{1}$, it also echoes the familiar heated - and in many ways unfair - misunderstanding of the EU, as we know it all too well in Denmark and other national contexts. The $\mathrm{EU}$ is often presented and perceived as an undemocratic, grey, bureaucratic giant that interferes in too much, whereas - a little pointedly expressed - the EU is not much more than what the governments of its member states can agree upon. In short, Brexit reveals that the UK is a divided nation.

Theresa May, the newly-elected leader of the Tory party and, consequently, the new prime minister, appears to support a more balanced Brexit than might have been feared if the process had been led by colourful Boris Johnson, who became Secretary of State for Foreign and Commonwealth Affairs instead. On 2 October Theresa May promised to trigger the infamous article 50 of the Lisbon Treaty in early 2017, with an expected formal UK exit by 2019.

The outcome depends on whether the UK and the EU can negotiate a so-called Norwegian or Swiss solution, whereby cooperation will probably continue as before, although the British will have to remain outside in the corridor when decisions are taken.

\footnotetext{
${ }^{1}$ For an informative account of this narrative about Britain's troubled relationship with Europe and the EU in particular, read Denis MacShane's book from 2015: Brexit: How Britain Will Leave Europe. London: J.B. Tauris \& Co. Ltd.
} 
Or, more likely, the UK and the EU will embark upon a long-term tug of war in which Realpolitik and common interests on economic, trade and security issues will eventually lead to a third way which small nations like Norway or Switzerland could never have achieved.

When following the British debate, one notes that the key British concern is about not losing full access to the EU single market. However, as vehemently reiterated by EU representatives, this full access requires compliance with the so-called 'four freedoms', comprising free movement within the EU for migrants/workers (including students), goods, services and capital. This condition will probably be hard to swallow for the considerable proportion of brexiteers who were primarily concerned with reducing immigration from countries like Poland, the Baltic countries and most recently Romania and Bulgaria. But then again, many brexiteers appeared to mix up the distinction between immigration from EU countries and third world countries.

\section{What will Brexit mean for European education and research?}

The short answer is: We do not know!

The slightly longer answer suggests that the political will to expand and deepen international collaborations within culturally sensitive areas such as schools and education will probably diminish for some years to come within the EU. Likewise, national protectionism can probably be expected to grow in terms of funding for research and a preference for own national students.

Collaboration with the UK within the OECD, the IEA and the Bologna Process will probably continue as before. The same most probably applies to the many-sided and diverse collaborations across borders between researchers and between students.

Regarding the prestigious Horizon 2020 programme (the EU's largest ever innovation and research programme, with a budget of nearly $€ 80$ billion) and other EU-funded research collaborations that Britons traditionally top in terms of winning grants, it is hard to imagine that the UK will not fight hard to remain within such golden schemes (http://ec.europa.eu/research/horizon2020/pdf/press/fact_sheet_on_horizon2020_bud get.pdf ). Immediately after the Brexit vote, one could read in British newspapers like the Guardian that British researchers and scientists are deeply concerned that they will be excluded from research collaborations (https://www.theguardian.com/education/2016/ jul/12/uk-scientists-dropped-from-eu-projects-because-of-post-brexit-funding-fears).

And yes, this has indeed already happened. EU researchers of other nationalities have expressed concern that they might jeopardise their chances of winning grants if they include British researchers because they do not know what Brexit agreements will apply in the near future. On the other hand, the British profit greatly from the advantage that English has become effectively EU's lingua franca, and that they have a privileged position in and access to the Globalisation Empire ${ }^{2}$ in research and education, which is largely defined by Anglo-Saxon nations and standards (USA, UK, Australia, Canada and New Zealand in particular).

Altogether, there are many indications that not much is going to happen - right now. Or maybe the opposite is the case: perhaps a lot of things are already beginning to happen, of which Brexit is just a part and a symptom.

\section{The big problem is our infantilised relationship with the EU}

Brexit has already had an unmistakable impact. Or perhaps it would be more accurate to characterise Brexit as a particularly radical echo of trends that proliferate in many - or

\footnotetext{
${ }^{2}$ Hardt, M., \& Negri, A. (2002). Empire. Cambridge, MA \& London: Harvard University Press.
} 
even most - other EU countries. For Brexit is also an expression of a particular and widespread kind of dissatisfaction with the way people believe or experience that the EU works. A kind of dissatisfaction that politicians can hardly ignore without risking an increase in support for EU-critical and populist parties on the right as well as the left sides of the political spectrum.

It is already apparent that the EU has reduced the amount of new legislation and is operating with a budget that is lower than last year. A discourse is on the rise that constantly talks in the tone of a so-called smaller and leaner EU, akin to the following: "the EU should focus on issues that require cross-national collaboration, but should refrain from interfering in affairs which are better dealt with at a national level". This discourse is usually built on the basic idea that the EU is a largely malevolent bureaucratic giant that erodes national sovereignty and democracy.

The question could be posed differently: Perhaps the problem is that we EU citizens harbour unrealistic expectations with regard to what the EU and Europe can accomplish with the current set-up. This situation is compounded by the fact that we have been guided for too long by too many national politicians and media who dare not or cannot find ways to convey to national audiences what collaboration within the EU actually involves and under which constraints. The result is too many infantilised national reactions and simplistic narratives about what goes on in the EU. In national politics the EU is blamed far too often when things go wrong, but is given no credit when things go well.

From a Danish context we know all too well what the consequences of ignorance about the EU and the way it works may be. A recent referendum (3 December 2015) on lifting a reservation concerning Danish participation in legal collaboration following the Danish "no" to the Maastricht Treaty (2 June 1992) was so badly explained and understood that, as usual, it became a referendum about whether you were for or against the EU. A rather similar thing happened recently in the Netherlands when the so-called Dutch UkraineEuropean Union Association Agreement referendum (6 April 2016) was turned in many respects into a popularity contest about whether you liked the EU or not. And most recently of all, the right-wing Hungarian Prime Minister Victor Orbán called for a referendum (2 October 2016), which he lost (in the sense that the voter turnout was too low) but continued to exploit nonetheless. This referendum concerned the EU resettlement quota for migrants arriving in Greece and Italy in particular. Hungary was scheduled to receive only around 1,300 asylum seekers according to the plan. This referendum was shrouded in rhetoric about the EU giant thwarting Hungarian national sovereignty and identity, and has raised debate questioning Hungary's place in the EU in the wake of Brexit. This rhetoric is evident in the way the question was posed in the referendum: "Do you want the European Union to be entitled to prescribe the mandatory settlement of non-Hungarian citizens in Hungary without the consent of parliament?" And I could continue with the French referendum rejection of the Lisbon Treaty in 2005 and other examples ${ }^{3}$.

I do not in any way deny that much critique can and should be raised about the transnational collaborations that Denmark and other European nation states are part of within the EU, the Bologna Process (the European Higher Education Area), the OECD (PISA, TALIS, etc.) and the IEA (PIRLS, TIMSS) ${ }^{4}$. In my view, there has certainly - albeit not exclusively - been too much focus on the economy, employment and employability, and

\footnotetext{
${ }^{3}$ E.g. Žižek, S. \& Horvat, S. (2015). What Does Europe Want?: The Union and Its Discontents. New York: Columbia University Press.

${ }^{4}$ IEA is the International Association for the Evaluation of Educational Achievement. IEA conducts TIMSS (Trends in International Mathematics and Science Study) and PIRLS (Progress in International Reading Literacy Study) and other comparative surveys of student achievement.
} 
often too much focus on the terms of a very neo-liberally oriented market perspective. In a school and education context there has been too much focus on surveys that are presented as mere rankings of nations, surveys which have also led to a one-sided emphasis on literacy, numeracy and science. The focus has been placed one-sidedly on school effectiveness, thereby generating a disregard for the knowledge and experience gained from broader Bildung and education perspectives that different countries have built up over many decades ${ }^{5}$.

Nonetheless, it is probably the case that Europe's many small and medium-sized nations (by global standards) would have adopted more inward-looking national identities and perspectives without the many transnational and international collaborations. Before joining the European Economic Community in 1973 together with the UK and Ireland, Danes used to regard their school system as the best in the world, and their society as an El Dorado in a dangerous world. So for Denmark as well as many other EU member states, the EU and other transnational collaborations have helped and still help to provide larger horizons and protect us from the seductions and temptations of inwardlooking self-sufficiency.

The EU is of course also merely a part - albeit a very substantial part - of much wider and thorough processes of internationalisation that operate at all kinds of levels: student, teacher and researcher mobility and international conferences; digital revolutions that have enabled students and researchers to interact globally on a daily level, exchanging emails and articles, debating on Skype with colleagues abroad and so forth. This expands the horizon infinitely in terms of opening up minds and experiences to other perspectives and other literary, argumentative, and educational and cultural worlds. Obviously, these processes have also been accompanied by increasing levels of inequality, which seriously need to be addressed. This inequality, however, is hardly an argument for prohibiting or rolling back such new opportunities. On the other hand, nor is it an argument for refraining from focusing upon, addressing and trying to change two of the largest - and granted - most serious problems in the EU as well as many other transnational collaborations:

1. There has been a one-sided focus on economic growth and market interests with a liberal ideological focus on the Single Market and its four freedoms. And paradoxically, in the light of Brexit, the British have been particularly successful in driving this agenda!

2. The democratic deficit: it has not been possible to strike a satisfactory balance in the institutional set-up and communication of what is happening in the EU. As a result, we have seen too often that policy-makers and the media have been unable to communicate EU issues, potentials and pitfalls to their respective national publics and their democratic forums in satisfactory ways. Venues have been missing too often for national populations or - ideally - European citizens to become engaged in discussing and helping to solve the many challenges that can probably only be solved transnationally.

Jürgen Habermas, the German philosopher and sociologist - one of my heroes in this context -, has argued for decades that the EU is probably the only institution with sufficient politically instutionalised power and enough weight and punch to potentially

\footnotetext{
${ }^{5}$ E.g.: 1) Krejsler, J.B. (2013). 'What Works' in Education and Social Welfare?: A mapping of the evidence discourse and reflections upon consequences for professionals. Scandinavian Journal of Educational Research, 7(1), 16-32.

2) Krejsler, J.B., Olsson, U., \& Petersson, K. (2014). The Transnational Grip on Scandinavian Education Reforms: The Open Method of Coordination Challenging National Policy-making. Nordic Studies in Education, 34(3), 172-186.
} 
match and challenge the excessively one-sided dominance of the market we have seen up to date ${ }^{6}$. He has warned convincingly that no European nation has the size and clout to establish a political frame to match market interests that increasingly defy national borders, for instance when multi-national companies as well as affluent citizens evade taxation and nation-state legislation. As Habermas himself has conceded, this struggle has only been partially successful. Many would likely say that it has failed. There is no doubt, however, that there are still plenty of hard battles to be fought to strike a more acceptable balance between a political system with democratic and popular legitimacy and the predominantly neo-liberally inspired market perspective that is dominant at present and for the foreseeable future.

But anyone who claims that these obstacles - however serious they may be - constitute a serious argument in favour of dismantling the EU ought to think twice. Without the EU, the domination of market forces would be even greater and more unchallenged. There would be a sea of small European nation states that would probably revert to the old national (and nationalist) habit of struggling for their own narrow national self-interests at the expense of their neighbours. This would create a Europe which would lose global influence, with each country probably being increasingly pitted against other countries by the dominant American, Chinese and Russian interests (just to name a few). This is already happening, but due not least to the existence of the EU it is still kept under at least some reasonable control. An illustrative example of this control is the recent ruling by the EU Commission that Irish preferential tax exemptions to Apple, the multinational giant, are illegal and the ensuing demand that Apple must repay the enormous amount that they have saved to the Irish state, against the will of the Irish government! This is an attempt to avoid a situation in which multinational companies pit nation states against each other to get extraordinarily preferential treatment that no small or medium-sized company would ever get (http://europa.eu/rapid/press-release_IP-16-2923_en.htm).

\section{Exit disaster or entry into a Kafkaesque process?}

So ultimately, I imagine that Brexit will probably mean:

1. that the UK will continue business as usual with EU countries, albeit with less influence;

2. that, for a number of years, EU collaboration will slow down, partly because of the immense effort to extricate the UK while simultaneously keeping them as intricately involved as the common interests of the UK and EU dictate;

3. that there will be more pressure in support of reforms of the EU that take the abovementioned problems seriously.

Presumably, this predominantly - but not exclusively - negative and reparative focus means that it will be somewhat more complicated to fight for and benefit from the many opportunities that EU collaboration has opened up. In an education and research perspective, the following issues are particularly relevant in this connection:

- increased student, teacher and researcher mobility;

- proliferation of research collaborations and knowledge dissemination.

Not least, the many perspectives and hence the critical mass of knowledge and diversity of collaboration within the EU represents, and has helped to qualify and open the often narrow national perspectives towards far larger horizons. And this undoubtedly constitutes perhaps the most valuable contribution in a larger Bildung or educational perspective!

${ }^{6}$ See for instance Jürgen Habermas (2013) The Crisis of the European Union: A response. London: New York: John Wiley \& Sons Inc. 